\section{FIFTH COMMONWEALTH ENTOMOLOGICAL CONFERENCE}

$\mathrm{B}^{\mathrm{B}}$ ECAUSE of the War, thirteen years have elapsed since the last Commonwealth Entomological Conference was held in London, and there is no doubt that the recent fifth Conference, which ended on July 29, has been the best attended and one of the most successful of the series. There were forty-two delegates, representing the United Kingdom, Canada, Australia, New Zealand, India, Southern Rhodesia and various Colonial territories, and the open meetings were attended also by large numbers of entomologists from Great Britain and overseas.

The first day was devoted to a discussion on insecticides and their application. This is the first time that this topic has appeared on the agenda of a Commonwealth Entomological Conference, and it was the only one to be given a full day.

The discussion on recent developments in insecticides was opened by Dr. R. A. E. Galley, scientific secretary to the Insecticides Development and Research Committee. He summarized the present knowledge on synthetic insecticides, many of which are still in the early experimental stage. Particular interest lies in the development of systemic insecticides which are absorbed by plants and thereafter toxic to insects which feed on them.

Dr. V. B. Wigglesworth, director of the Unit of Insect Physiology of the Agricultural Research Council, in $\mathrm{a}_{\mathrm{a}}$ discussion on the mode of action of the new insecticides, said that D.D.T. if injected internally was almost equally toxic to insects and verte. brates. The reason that the former are so readily affected if they come in contact with D.D.T.-treated surfaces, while the latter are unharmed, is because of the readiness and rapidity with which absorption takes place through the insect cuticle. An account of Canadian experience with the new insecticides was given by Mr. W. A. Ross, of the Canadian Department of Agriculture, who stated that, of them, D.D.T. was the one most extensively used. Because of the great increase in the importance of orchard mites following the use of D.D.T., a search for efficient acaricides is one of the principal problems of fruit insect research in Canada. Several promising ones have already received preliminary investigation.

A discussion on the application of insecticides from the air was opened by Dr. D. L. Gunn, of the AntiLocust Research Centre. After mentioning the question of costs, Dr. Gunn spoke of the importance of ensuring a sufficiently homogeneous coverage of the target area. He pointed out that while a great deal of publicity has been given to aircraft spraying, and while in certain circumstances it would undoubtedly prove of value, little is yet known as to whether it can establish itself in competition with other methods.

Dr. W. R. Thompson, of the Commonwealth Bureau of Biological Control, who was to have opened the discussion on the biological control of insects, was unable to be present, and this session was opened by Mr. A. B. Baird, of the Canadian Department of Agriculture. Mr. Baird gave an account of the work of the Bureau of Biological Control since the last Conference, and spoke also of projects, mostly involving forest insect pests, with which he had been associated. Dr. W. Cottier, of New Zealand, followed with an account of the successful biological control of the small cabbage-white butterfly (Pieris rapa L.) in
New Zealand, and Dr. R. H. Le Pelley described the steps leading up to the control, by means of introduced parasites, of the coffee mealy bug in Kenya. This insect has at different times passed under different names, and this led to the search for parasites, made in the early stages of the investigation, being misdirected. When it was eventually realized that the injurious mealy bug was an undescribed species, native to the adjoining territory of Uganda, the parasite search became properly directed and was successful.

Some account of the general principles of the biological control of weeds by means of insects was given by Dr. D. Miller, of the Cawthron Institute, New Zealand. He also outlined particulars of some of the weed control projects which have been undertaken in New Zealand. These have been concerned with gorse, Accena sp., and ragwort.

Mr. A. H. Strickland of the West African Research Institute, Tafo, Gold Coast, presented an able summary of special techniques relating to the estimation of insect populations in the field. $\mathrm{He}$ is of the opinion that little purpose is served by carrying out insect census work unless a preliminary detailed study has been made of the biology and habits of the species of insects concerned.

The discussion on recent developments in the control of stored products insects was opened by Mr. F. N. Ratcliffe, of the Division of Entomology of the Australian Council for Scientific and Industrial Research. He confined his remarks to wheat insects, and mentioned that the exploitation of D.D.T. and benzene hexachloride against grain insects is at present limited by the prevalent fear of their toxicity to human beings. In conclusion he stressed the importance of scientific men who work in this field having a knowledge of the manipulating conditions of the grain industry.

The subject of tsetse fly research and control was opened by Dr. T. A. M. Nash, and Dr. K. R. S. Morris took a prominent part in the discussion. Dr. Nash indicated the main lines in which research has been conducted; he remarked that each of the seven most important species of Glossina has different vegeta. tional and climatic requirements, host preferences, and characteristic behaviour. While many methods of control have seemed promising, they have usually failed to produce complete elimination of the fly, with the result that as soon as control measures are relaxed, the fly density starts to rise.

In a discussion of the need for plant quarantine on a continental basis with special reference to Africa, delegates from various African territories gave parti. culars of the plant quarantine practice in their areas. The danger that might arise from uncontrolled air transport was emphasized.

Dr. B. P. Uvarov, who opened the discussion on locusts and grasshoppers, said that the outstanding result of the past twenty years of locust investigation is the firm establishment of the principle of outbreak areas, where the initial transformation of the solitary phase into the gregarious phase occurs and the first swarms of a plague-cycle are formed. While of recent years great strides have been made in discovering and applying effective palliatives, these must not be regarded as the end-point of the investigation; a radical solution of the problem must be sought in outbreak prevention, which needs more fundamental research.

Following the discussion on locusts and grass. hoppers, the remaining part of the last afternoon was 
spent considering the recommendations of a Termite Sub-Committee which had been set up at an early stage of the Conference. These recommendations stressed the urgent need for research work on termites, particularly in the Colonies.

During the course of the Conference, delegates visited Whipsnade, Rothamsted Experimental Station, the Pest Infestation Laboratory of the Department of Scientific and Industrial Research at Slough and the new entomological Field Station of the Imperial College of Science and Technology at Silwood Park. These visits, combined with certain social occasions, served to give delegates that chance of informal discussion which is perhaps the most valuable part of a conference of this nature.

\section{FOSSIL FLORA OF KERGUELEN ISLAND}

$\mathrm{T}$ HE biological interest of Kerguelen Island (latitude $49^{\circ} \mathrm{S}$., longitude $69^{\circ} \mathrm{E}$.) has been well known to botanists since 1847, when the young Joseph Hooker, as junior surgeon in Ross's famous voyage to the Antarctic in the Erebus and Terror, contributed a description ${ }^{1}$ of the botany of this island gained as the result of the expedition's first winter in the southern hemisphere (May-July, 1840). The extreme poverty of the flora was its most noticeable feature, only eighteen species of flowering plants having been found by Hooker, and of these only eight covered any considerable expanse of ground. These included the remarkable endemic crucifer, Pringlea antiscorbutica (the Kerguelen Island cabbage), and a peculiar umbellifer related to the 'balsam bog' of the Falkland Islands. In comparable latitudes in the northern hemisphere much richer floras were known to occur, the vegetation of Spitsbergen, for example, containing records in 1847 of forty-five species of flowering plants on a comparable area. This, coupled with the isolated position of the island in the middle of the Antarctic Ocean, almost equidistant from South Africa and from Australia, the presence of the endemies and the vegetational affinity with the even more distant Falkland Islands (off Cape Horn), are all problems of lively plant-geographical interest to us as to Hooker. Problems of equal interest are those raised by the very marked changes of climate which have occurred in these now desolate latitudes in fairly recent geological time. Hooker himself was pro. foundly impressed by seeing not only coal but also fossilized tree trunks of considerable size (one is specifically mentioned by Ross as $7 \mathrm{ft}$. in circum. ference), although the existing vegetation cannot boast even a shrub, still less a tree, and this circumstance was certainly one of the more powerful reasons which predisposed him to the immediate acceptance of the idea of evolution when it came.

The fossil woods brought back by the Ross expedition were not further investigated until 1921, when Edwards ${ }^{2}$ of the British Museum identified them as coniferous. Shortly after this in 1934 Seward and Conway $^{3}$ identified araucarian twigs and cone scales in some macroscopic plant remains brought back by de la Rue in 1931. This material also contained the remains of a moss and some indeterminate fragments of dicotyledonous leaves and ferns.

An additional contribution is now available in the eighth part of vol. 2 (pp. 129-142) of the Reports of the British, Australian and New Zealand Antaretic Research Expedition of 1929-31, published at Adelaide, 1947, under the title of "Plant Microfossils from the Lignites of the Kerguelen Archipelago by Isabel C. Cookson" (price 4s. 6d.). This is one of the few applications of the pollen analysis technique to fossil floras of the southern hemisphere, and though carried out on very limited material the results add greatly to previous knowledge while holding out considerable hope of more to come.

As was to be expected from Seward and Conway and from Edwards, araucarian pollen predominates. This is, however, not the only gymnosperm present. Five distinguishable species, undoubtedly belonging to the Podocarpacere though of less certain generic identity within that family, are listed under the form genera of Disaccites (Podocarpidites), Polysaccites (Microcachryidites) and Disaccites (Phyllocladidites). Angiospermous pollen is also present though more sparingly, five species only being so far recorded, three of which appear to be dicotyledons and two mono. cotyledons. In contrast there are ten varieties of Pteridophyte spores, probably of ferns, but not identifiable generically. There are likewise two species of ascomycetous fruit body.

While the available information does not yet permit of a generalized palæoecological statement to be made of this most interesting region it seems clear that gymnosperms and ferns predominate in the lignites so far examined, the age of which is on that account thought to be Tertiary. It is greatly to be hoped that this work will be further extended by a systematic study of additional collections and through the whole thickness of the deposits.

${ }^{1}$ Ross, J. C., "A Voyage of Discovery and Research in the Southern and Antarctic Regions during the Years 1839-43" (London, 1847). ${ }^{2}$ Edwards, W. N., Ann. Bot., 35, 609 (1921).

${ }^{3}$ Seward, A. C., and Conway, V., Ann. Bot., 48, 715 (1934).

\section{BIOLOGY AND CONTROL OF THE PEA MOTH}

$\mathrm{T}$ HE pea moth, Laspeyresia nigricana, Steph., is a widely distributed pest of garden and field peas in Great Britain and central and southern Europe, while in North America it has spread to all main pea-growing areas. In England the most severe losses occur in the pea-producing counties of Lincoln, Essex and Kent. D. W. Wright and Q. A. Geering, of the Horticultural Research Station and School of Agriculture, Cambridge, have published a useful paper on the biology and control of the pea moth (Bull. Entom. Res., 39, pt. 1, 57 ; 1948).

It appears that the moths show no special preference for ovipositing on or near the flowers or pods. The larva feeds on the young seeds in the pod and bores a hole through the pod-wall for the purpose of reaching its food. The hole heals over, however, in a few days, leaving a small blister. When fully grown the larva spins a thin, web-like cocoon imme. diately below the soil surface, wherein pupation takes place. The majority of the moths emerge before the end of July in the following year. Normally there seems to be only a single generation of this insect in Britain.

The trials that were carried out indicate that different varieties of peas differ widely in their 